\title{
Некоторые особенности флористического и фитоценотического разнообразия ильмовников с Ulmus pumila L. в Западном Забайкалье
}

\section{Some features of the floristic and phytocoenotic diversity of Ulmus pumila L. communities in Western Transbaikalia}

\author{
Холбоева С. А. \\ Kholboeva S. A. \\ Бурятский государственный университет, г. Улан-Удэ, Россия. E-mail: kholboeva@mail.ru \\ Buryat State University, Ulan-Ude, Russia
}

Peферат. В работе рассматриваются некоторые особенности флористического и фитоценотического разнообразия сообществ Ulmus pumila L. в пределах Западного Забайкалья. Наибольшие площади занимают коренные склоновые ильмовники, а также сообщества ильмовников на разновозрастных залежах. Проведен сравнительный анализ систематической, экологической, биоморфологической структуры ценофлор залежных и коренных сообществ ильмовников. Спектр преобладающих семейств и родов в ценофлорах показывает их высокое сходство. Спектр экологического и биоморфологичесого состава ценофлор подтверждает ее степной характер и высокий уровень адаптации U. pumila к аридным условиям степей региона. Анализ фитоценотического разнообразия позволяет предположить, что восстановительная сукцессия с участием ильма на залежных участках, расположенных в основном на выровненных и пологосклоновых поверхностях днищ котловин, приводит к формированию ильмовников с преобладанием рыхлодерновинных злаков в травянистом ярусе.

Ключевые слова. Западное Забайкалье, растительное сообщество, ценофлора, Ulmus pumila.

Summary. The paper discusses some features of the floristic and phytocoenotic diversity of Ulmus pumila L. communities in Western Transbaikalia. The indigenous elm communities on slope and communities on postagrogenic fallow lands occupy the largest area. A comparative analysis of systematic, ecological, biomorphological structure between the coenofloras of fallow and indigenous elm communities was carried out. The spectrum of predominant families and genera in the coenofloras shows their high similarity. The range of environmental and biomorphological composition of studied elm coenofloras confirms its steppe character and a high level of adaptation of U. pumila to the arid conditions of the steppe region. Analysis of phytocoenotic diversity suggests that the recovery succession with the participation of $U$. pumila in the fallow areas, located mainly on the leveled and flat surfaces of the basins bottoms, leads to the formation of elm communities with the predominate of friable turf grass in herb layer.

Key words. Coenoflora, plant community, Ulmus pumila, Western Transbaikalia.

Одним из интереснейших представителей флоры Забайкалья является ильм низкий или приземистый - Ulmus pumila L. Это невысокое дерево с редкой раскидистой кроной - единственное дерево, способное произрастать и формировать сообщества в полном окружении степной растительности Бурятии. Естественный ареал вида охватывает север Центральной Азии, включая лесостепную, степную и даже полупустынную зоны, а также пойменные экосистемы рек (Ареалы ..., 1977). Реликтовое происхождение U. pumila обсуждается в ряде работ (Пешкова, 1972; Камелин, 1987; Намзалова, Сахьяева, 2016).

В Западном Забайкалье $U$. pumila встречается в пределах Селенгинского среднегорья по склонам предгорий и возвышенностей и в долинах рек в степном и лесостепном поясах. В южных районах Селенгинского среднегорья ильмовники приурочены к ложбинам стока в предгорьях, на южных шлейфах невысоких отрогов. В среднем сомкнутость крон деревьев, как правило, очень низка (до 0,3), местами деревья встречаются единично. 
Всего учтено 171 описание с участием $U$.pumila. В анализ коренных сообществ включено 23 геоботанических описания с обилием U. pumila от 1 и более баллов по шкале Браун-Бланке и формированием ильмом заметного яруса; в анализ залежных сообществ включено 18 описаний.

Анализ экотопической приуроченности и генезиса сообществ $U$. pumila выявил их большое разнообразие.

1. Естественные (коренные) ильмовники. Ильмовники склоновые петрофитные, часто с развитым кустарниковым ярусом (Spiraea aquilegifolia, Armeniaca sibirica и др.). и степным травянистым покровом распространены в пределах Селенгинского среднегорья на склонах сопок и хребтов, склонах террас (Холбоева, 2018).

Пойменные травяные ильмовники встречаются в поймах р. Селенги и ее притоков. Деревья $U$. pumila имеют здесь наибольшую высоту (до 10 м) и диаметр ствола (до 20-25 см). Подобные сообщества близки к исходному генетическому варианту неморальных ильмовников, в настоящее время распространенных в восточных частях ареала (Беликович, Галанин, 2006).

Псаммофитные ильмовники на зарастающих песках Забайкалья описаны Дулеповой Н. А. (2014). В большинстве это сообщества с разреженным травянистым покровом из корневищных злаков (Agropyron michnoi, Festuca dahurica) и кустарником Caragana buriatica.

2. Вторичные ильмовники формируются путем естественного семенного возобновления в трансформированных биоценозах. Залежные ильмовники сформированы на днищах котловин и на низких террасах (Холбоева и др., 2018) на заброшенных пашнях. Визуально хорошо отличаются от естественных сообществ ровными границами контуров, относительно молодым возрастом, плотностью зарослей и кустарниковой формой ильма.

Рудеральные группировки ильмовников распространены в пределах населенных пунктов, прежде всего в г. Улан-Удэ, часто на антропогенных субстратах, на обочинах дорог, вдоль заборов, на пустырях.

3. Культивированные антропогенные ильмовники. Лесополосы из $U$. pumila были высажены в 1970-80-х гг. в пределах естественного ареала для защиты полей от ветровой эрозии. В настоящее время контроль и уход за ними отсутствуют; деревья старые, много сухостоя.

Ильмы в составе озеленения (в г. Улан-Удэ) использованы в одиночных и групповых посадках вдоль зданий и дорог. Имеются деревья естественного семенного происхождения, крона которых была сформирована обрезкой.

Наибольшие площади из перечисленных занимают коренные склоновые ильмовники, а также залежные; соответственно, их ландшафтная значимость наиболее высокая, в связи с чем в качестве объектов исследования выбраны эти типы сообществ.

Нами составлен перечень видов высших сосудистых растений, зарегистрированных в описаниях (табл.). Проведено сравнение ценофлор коренных и залежных ильмовников.

Список ведущих семейств и родов ильмовников как коренных, так и залежных (Asteraceae, Fabaceae, Rosaceae, Poaceae, Lamiaceae), характерен для степной флоры Сибири (Рещиков, 1961; Пешкова, 2001) и дает основание рассматривать в качестве ведущего фактора степной генезис флоры ильмовников. Выявлена степень сходства типов ильмовников, коэффициент Жаккара составляет 0,312.

Родовой спектр ценофлор весьма своебразен. Так, на первом месте в обеих ценофлорах представлен род Artemisia (10 видов (6,1\%) в коренных ильмовниках и 7 видов (7,3\%) в залежных). Далее общим является Potentilla (2,4 \% и 3,1 \% соответственно), остальные рода (Allium, Thalictrum, Oxytropis, Astragalus) представлены 2-3 видами (2 и менее \%). Подобная таксономическая структура отражает рудеральный характер формирования сообществ, формирующихся в сухостепных условиях, при этом на залежах нарушения почвенного покрова вызваны распашкой с последующим забрасыванием, в естественных условиях - склоновыми процессами.

Сравнение соотношения поясно-зональных групп в обеих ценофлорах выявляет преобладание степных элементов ( 83 \% в залежных, 85 \% в коренных) и их схожесть (рис. 1), при этом наиболее высока доля горностепных и собственно степных видов. 
Ведущие семейства во флоре коренных и залежных ильмовников

\begin{tabular}{|c|l|c|c|c|c|}
\hline \multicolumn{2}{|c|}{ Флора коренных ильмовников } & \multicolumn{2}{c|}{ Флора залежных ильмовников } \\
\hline №мейство & \multicolumn{1}{|c|}{ Семе } & место & $\%$ & место \\
\hline 1 & Asteraceae & 16,4 & 1 & 13,5 & 1 \\
\hline 2 & Fabaceae & 10,3 & 2 & 12,5 & 2 \\
\hline 3 & Rosaceae & 9,1 & 3 & 6,3 & $4-5$ \\
\hline 4 & Poaceae & 8,5 & 4 & 10,4 & 3 \\
\hline 5 & Lamiaceae & 5,5 & 5 & 6,3 & $4-5$ \\
\hline 6 & Caryophyllaceae & 4,2 & 6 & 3,1 & $8-11$ \\
\hline 7 & Ranunculaceae & 3,6 & 7 & 4,2 & 7 \\
\hline 8 & Allyaceae & 3,0 & $8-11$ & 3,1 & $8-11$ \\
\hline 9 & Apyaceae & 3,0 & $8-11$ & - & - \\
\hline 10 & Chenopodiaceae & 3,0 & $8-11$ & 2,1 & 6 \\
\hline 11 & Brassicaceae & 3,0 & $8-11$ & 5,2 & \\
\hline & Bсего видов & 165 & & 96 & \\
\hline
\end{tabular}

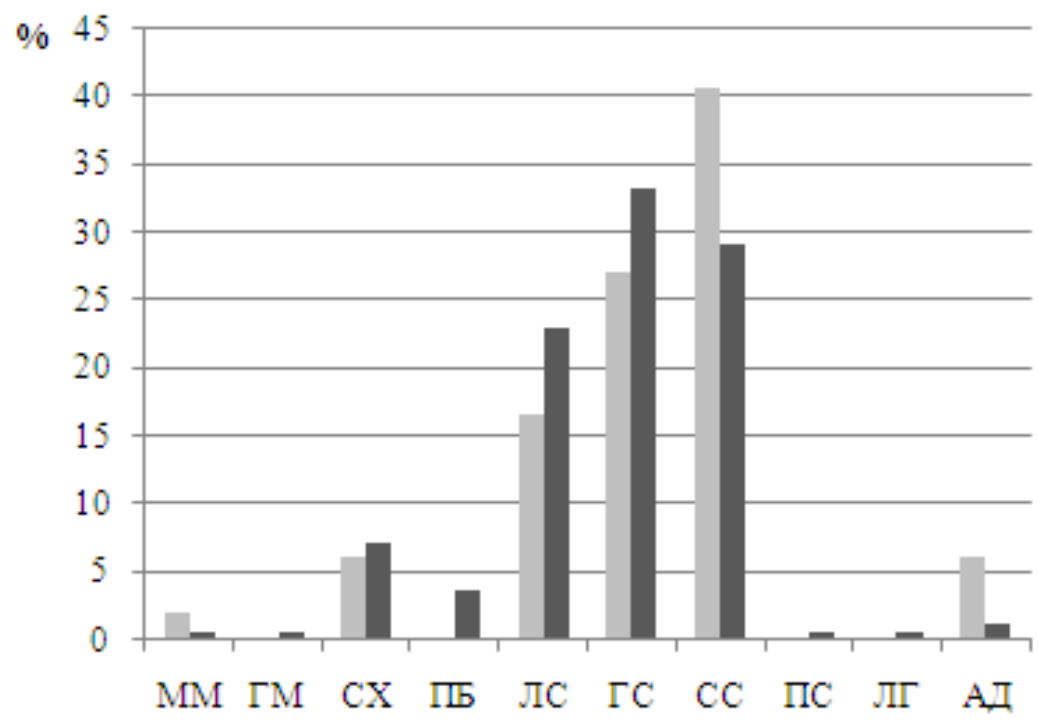

\section{Итьмовники залежные}

Итьмовники коренные

Рис. 1. Поясно-зональные элементы ценофлоры ильмовников: ММ - горный общепоясной; ГМ - гипарктомонтанный; СХ - светлохвойный; ПБ - пребореальный; ЛС - лесостепной; ГС - горностепной; СС - собственно степной; ПС - пустынно-степной; ЛГ - луговой; АД - адвентивный.

Биоморфологическая структура (рис. 2) рассматриваемых ценофлор также имеет сходный спектр: преобладают стежнекорневые поликарпики, высока доля монокарпических трав. В сравнении со степными травянистыми ценозами низка доля участия дерновинных трав. Сравнение спектров между собой показывает незначительные отличия: в залежных сообществах ильмовников выше доля монокарпиков, что объяснимо поселением и разрастанием сорных видов; также ниже участие кустарников, которые характерны в основном для каменистых склонов коренных сообществ.

В целом флора коренных ильмовников соответствует характеристикам степной флоры Южной Сибири, что позволяет сделать вывод о высоком уровне адаптации $U$. pumila к аридным условиям степей региона. Сходство ценофлор залежных и коренных ильмовников подтверждает данный вывод.

Фитоценотическое разнообразие ильмовников достаточно высокое. В склоновых естественных ильмовниках выделены наиболее широко распространенные фитоценозы: ильмовник абрикосово-леспедецевый, ильмовник водосборолистноспирейный (ильмовник спирейно-бесстебельнолапчатковый, ильмовник спирейно-гмелинополынный), ильмовник мятликовый. 


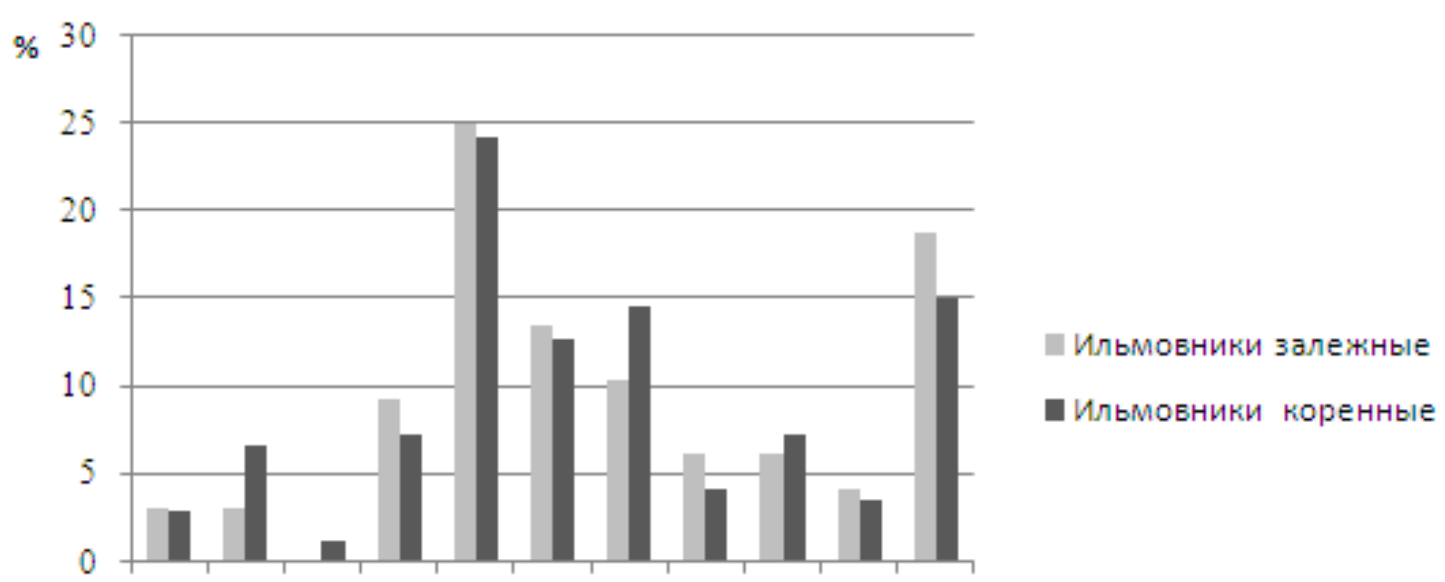

$\begin{array}{llllllllllll}\text { ДВ } & \mathrm{KC} & \mathrm{K} & \Pi \mathrm{I} & \mathrm{CK} & \text { ДK } & \mathrm{KK} & \mathrm{P} Д & \Pi \text { ПД } & \mathbb{I} & \mathrm{MO}\end{array}$

Рис. 2. Жизненные формы: ДВ - деревья; КС - кустарники; ПК - полукустарники и полукустарнички; КЧ - кустарнички и полукустарнички; ДК - длиннокорневищные; СК - стержнекорневые; КК - короткокорневищные; ПД - плотнодерновинные; РД - рыхлодерновинные; Л - луковичные и клубневые; Мо - однолетние и двулетние монокарпики.

На разновозрастных залежах нами отмечены сообщества, соответствующие разным стадиям восстановительной сукцессии (Холбоева и др., 2018). На бурьянистой стадии: ильмовник веничнополынный; на рыхлодерновинной стадии: ильмовник сибирскочиевый, ильмовник леспедецево-мятликовый. При наличии выпаса формируется дигрессионная стадия: ильмовник холоднополынный, ильмовник твердоватоосоковый. На залежах на песчаных почвах: ильмовник китайсковострецовый.

На зарастающих песках описаны фитоценозы ильмовников бурятскокараганово-даурскотипчаковых.

Анализ фитоценотического разнообразия позволяет предположить, что восстановительная сукцессия на залежных участках, расположенных в основном на выровненных и пологосклоновых поверхностях днищ котловин, приводит к формированию травянистых ильмовников, с преобладанием рыхлодерновинных злаков, без выраженного участия кустарников, обычных для коренных ильмовников.

\section{ЛИТЕРАТУРА}

Ареалы деревьев и кустарников СССР: в 3 т. Т. 1. Тиссовые - Кирказоновые / С. Я. Соколов, О. А. Связева, В. А. Кубли. Академия наук СССР, Ботанический институт им. В. Л. Комарова. - Л.: Наука, 1977. -164 с.

Беликович $\boldsymbol{A}$. В., Галанин $\boldsymbol{A}$. B. Забайкальский харганат как тип растительности // Комаровские чтения. - Владивосток: Дальнаука, 2006. - Вып. 52. - С. 98-126.

Дулепова Н. А. Флора и растительность развеваемых песков Забайкалья: автореф. дис. ... кандидата биологических наук. - Новосибирск, 2014. - 17 с.

Камелин Р. В. Флороценотипы растительности Монгольской Народной Республики // Бот. журн., 1987. - Т. 72 , № 12. - C. $1580-1595$.

Намзалов Б. Б., Сахьяева А. Б. К характеристике реликтового сообщества ильмовой лесостепи в долине р. Джида (Западное Забайкалье) // Эволюция и современное состояние ландшафтов и биоты Внутренней Азии: Материалы Всеросс. конф., посвящ. 75-летию со дня рождения и 50-летию научной и научно-педагогической деятельности профессора А. Б. Иметхенова, 2016. - С. 177-180.

Пешкова Г. А. Флорогенетический анализ степной флоры гор Южной Сибири. - Новосибирск: Наука, 2001. $-192 \mathrm{c}$.

Рещиков М. А. Степи Западного Забайкалья. - М.: Изд-во АН СССР,1961. - 176 с.

Холбоева $\boldsymbol{C}$. $\boldsymbol{A}$. Характеристика ценофлоры Ulmus pumila L. в Западном Забайкалье // Вестник Бурятского государственного университета. Биология. География. - Улан-Удэ: Изд-во Бурятского госуниверситета, 2018. №2. - C. 10-23.

Холбоева С. А., Сахьяева А. Б., Абашеев Р. Ю. Восстановительные сукцессии с участием Ulmus pumila L. на залежах Западного Забайкалья // Вестник Северо-Восточного федерального университета им. Аммосова. Якутск, 2018. - Вып. 6 (68). - С. 43-54. 